NBER WORKING PAPER SERIES

\title{
CROWDING-OUT CHARITABLE CONTRIBUTIONS IN CANADA: NEW KNOWLEDGE FROM THE NORTH
}

\author{
James Andreoni \\ A. Abigail Payne \\ Working Paper 17635 \\ http://www.nber.org/papers/w17635
NATIONAL BUREAU OF ECONOMIC RESEARCH
1050 Massachusetts Avenue
Cambridge, MA 02138 \\ December 2011
}

This research was supported by grants from the Social Sciences and Humanities Research Council of Canada, and the National Science Foundation. The views expressed herein are those of the authors and do not necessarily reflect the views of the National Bureau of Economic Research.

NBER working papers are circulated for discussion and comment purposes. They have not been peerreviewed or been subject to the review by the NBER Board of Directors that accompanies official NBER publications.

(C) 2011 by James Andreoni and A. Abigail Payne. All rights reserved. Short sections of text, not to exceed two paragraphs, may be quoted without explicit permission provided that full credit, including (C) notice, is given to the source. 
Crowding-Out Charitable Contributions in Canada: New Knowledge from the North

James Andreoni and A. Abigail Payne

NBER Working Paper No. 17635

December 2011

JEL No. D64,H44,H5

\begin{abstract}
$\underline{\text { ABSTRACT }}$
Using data from charitable organizations in the US, authors have established that government grants to charities largely crowd out giving from other sources, but that this reduction is due mostly to reduced fundraising activities of the charity itself. We use much more detailed data from over 6000 charities in Canada, measured for up to 15 years, to provide valuable new insights into this phenomenon. In particular, dollars received from individuals is largely unchanged by government grants. Instead, the crowding out is attributable to two other sources of donations not differentiated in US data: giving from other charities and charitable foundations, and donations gained from special fundraising activities, like galas or sponsorships. Only the latter-which is about half of the measured crowding out-represents a potential loss of dollars to the charitable sector as a result of government grants.
\end{abstract}

James Andreoni

Department of Economics

University of California, San Diego

9500 Gilman Drive

La Jolla, CA 92093-0508

and NBER

andreoni@ucsd.edu

A. Abigail Payne

Department of Economics

McMaster University

KTH 426, 1280 Main Street West

Hamilton, Ontario, Canada L8S 4M4

paynea@mcmaster.ca 


\section{Introduction}

With a population of over 32 million, Canada is ranked by the IMF as the tenth richest country in the world with per capita income in 2011 of nearly $\$ 40,000$ (US). It is also one of the most charitable countries in the world. Sixty-four percent of Canadians report giving to charity each year, compared to 60\% of Americans, and donors gave a total of \$8.2 billion (US) in 2009. Canada's per capita giving was $0.72 \%$ of GDP in 2006, ranking third internationally, after the US (1.67\%) and the UK (0.73\%). ${ }^{1}$ This paper uses government filings of over 6500 Canadian charities, spanning up to 15 years to study how government grants to charities affect direct donations of givers, fundraising expenses of charities, and the net effect on the charitable dollars received by the organizations. This question of government crowd out is one of the oldest and most important public economics issues and has been studied extensively in the US. This, we believe, is the first study of its kind for Canada.

The analysis here will follow that of Andreoni and Payne (2011, 2003). Using US data, both studies explored the displacement of fundraising when a charity receives government funding. Andreoni and Payne (2011) extended the analysis by decomposing the effect of government grants into the classic direct crowding out of private donors and the indirect crowding out due to reduced fundraising. They found that total crowding out is close to 75 percent and that most of this crowding out is attributable to reduced fundraising by the charity.

Here we expand Andreoni and Payne’s (2011) analysis to Canada. There are three main reasons for doing this. Foremost is that the data from Canada is of far greater quality than that available from the United States. Hence, the data used here can potentially give a clearer picture of the relationship between charities, the government and donors. And because of extra

\footnotetext{
${ }^{1}$ Sources: IMF; Charities Aid Foundation, The World Giving Index 2010; CAF Briefing Paper: International comparisons of charitable giving, November 2006.
} 
precision of the source of donations, we are able to gain insights into charitable giving that would not be possible with U. S. data. As added benefits, we can also inform important policy questions for Canada and, by sharpening the findings of Andreoni and Payne (2011), bolster the policy prescriptions for the U.S. as well.

What makes the data on Canada superior to data used in other studies? First is a long panel on charities. We were able to obtain the annual tax filings of Canadian charities from 1992 to 2006. In our final sample we have a panel of nearly 68,150 observations. Second, these tax filings are far more detailed and precise than US 990 forms used earlier. Third, the Canadian census is taken every 5 years, as opposed to 10 years in the US, and reported census block averaging is on a scale that is typically much finer than in US data, thus giving us more demographic accuracy about the geographic area surrounding the charity. Fourth, the variation in political representation is quite high and cannot be thought to be correlated with giving in the districts, thus has potential as a valuable instrument. Fifth, Canadian giving is reported in three primary categories: Tax Receipted Gifts are donations that generate a receipt for tax purposes and include most direct contributions by individuals; Revenue from Fundraising is a slightly misleading term that refers to revenues from, for example, special fundraising events such as a gala or sponsorship; finally, Revenue from other Charities includes mostly gifts from foundations to the charitable service organizations.

The findings of the paper are striking. Estimates of gross crowding out exceed 100 percent, of which 80 percent can be attributed to reduced fundraising by the charities. Both figures are similar to the US data. However, when analysis of giving is divided into the three categories, we find further insights. In particular, tax receipted gifts are crowded-in by government dollars, consistent with several theories of grants as signals or as seeds (Andreoni, 
1998, 2006), while 75 percent of revenue from other charities is directly crowded out by government grants. The area most affected by grants, however, is revenue from fundraising.

This tells an interesting story. Individuals, who are likely the least well informed of the finances or effectiveness of a charity use the grants as a signal of quality and are thus encouraged to give by government grants, while donations from foundations and other charities, who are likely the most well informed, are by contrast discouraged by grants. Finally, the revenue from fundraising, probably the most onerous type of fundraising by charities, is the kind of giving that suffers the most when grants are received, underscoring the assumption made in many models of fundraising that charities find it a necessary but unpleasant activity.

In telling this story, however, one must be careful to remember that charities are in long term relationships will all of their contributors, and our analysis is not able to capture all the richness about how grants and fundraising may influence these relationships.

The paper proceeds as follows. Section 2 gives the background for our analysis. Section 3 describes the Canadian data. Section 4 provides our estimation model and results, while Section 5 is a conclusion.

\section{Framework for Analysis}

In this section, we summarize the prior literature and discuss how the special features of our data allow us to expand the questions to decompose crowd-out into several types of private giving.

\section{A. Background}

The previous literature on fundraising has considered three main actors in the charitable sector: The charities that solicit funds, individual donors who also pay taxes, and the government which spends tax revenues on grants to charities. The dye cast in our previous papers (Andreoni 
and Payne, 2003, 2011) is to think of these players as interacting in a market for charitable giving (Andreoni 2006a, List 2011).

In this market, charities are the demanders of donations and compete with other charities to attract the suppliers of donations. These suppliers are concerned with the quality of charities and the effectiveness of their donations, on which they likely have only partial information, while they also care about the costs and convenience of donating. Fundraising can reduce the costs of donating by, for instance, soliciting donations over the phone. Fundraisers can also provide information that could attract givers. However, excessive fundraising is also wasteful, and can potentially deter givers (Rose-Ackerman, 1982, Okten and Weisbrod 2000).

Grants from the government have two possible effects. First is the traditional crowding out argument: Individuals involuntarily pay the taxes that then go to the charity, hence people optimally withdraw their voluntary donations in response (Warr 1982, Bergstrom, Blume, and Varian, 1986). But if the quality or effectiveness of the charity is unknown, the fact that a charity applied for and won a government grant conveys positive information about the charity, hence may encourage more giving (Andreoni, 1998, 2006b, Vesterlund 2003).

In a recent theoretical contribution, Correa and Yildirim (2011) provide an extremely elegant and general approach to this complex set of interactions. Like prior models (Andreoni and Payne, 2003), they assume that individuals do not give unless they are solicited directly (see Meer and Rosen, 2011, and Andreoni and Rao, 2011, and Andreoni, Rao, and Trachtman, 2011 for evidence of this effect), and that fundraising is an activity that charities consider a "necessary evil," that is, they must do it but would prefer to devote the same efforts and dollars to their charitable mission. Correa and Yildirim predict that government grants should result in lower fundraising efforts, reduced private giving, but incomplete crowding out. 


\section{B. Framework for Analysis}

In addition to the three actors discussed above, we now must also consider a fourth actor: Foundations and other nonprofits that give directly to charities. Unlike private donors, these institutional donors are likely to be quite well informed about the quality and finances of charities. But as with private donors, there are costs of attracting institutional gifts, such as making applications and accounting for expenses. In contrast to private donors, government grants are less likely to provide any signaling value to institutional donors, and more likely to make the donor institution feel their marginal impact has been reduced, leading to lower giving and more crowding out.

A further difference is that our data also divides individual donations into two pieces. The tax receipted gifts are the type of donation that Andreoni and Payne (2003) and Correa and Yildirim (2011) have in mind. Revenues from fundraising, such as sponsoring a run or holding a banquet, is a refinement of giving and fundraising calculus that has yet to be explored either in theory or empirically. Intuitively, one might expect that fundraising from sponsored events is most disruptive to the charity since it requires more "hands on" effort than a mailing or phone bank, that is, tax receipted gifts. Hence, one would not be surprised to find this activity crowded out to a greater degree than other types of fundraising.

While our data gives us precise information on fundraising, it unfortunately does not

disentangle dollars spent on fundraising from tax receipted gifts, revenues from fundraising, and revenues from other charities. However, if we assume that a charity is spending its fundraising budget optimally, the budget should be allocated across the three activities in a such that the marginal returns from the last dollar spent on each is equal. 
Let $D_{i}$ be donations from source $i$, so that total donations are $D=D_{1}+D_{2}+D_{3}$.

Likewise, let $F_{i}$ be the dollars spent on fundraising from $i$, so $F=F_{1}+F_{2}+F_{3}$. Then by definition

$$
\frac{d D}{d F}=\frac{d D_{1}}{d F_{1}} \frac{d F_{1}}{d F}+\frac{d D_{2}}{d F_{2}} \frac{d F_{2}}{d F}+\frac{d D_{3}}{d F_{3}} \frac{d F_{3}}{d F}
$$

The assumption of efficient fundraising implies that $d D_{i} / d F_{i}$ be identical for all activies. Hence, $d D / d F=\left(d D_{i} / d F_{i}\right)\left(d F_{1} / d F+d F_{2} / d F+d F_{3} / d F\right)$, that is, $d D_{i} / d F_{i}=d D / d F$ for all $i$.

Since our data will allow us to identify the combined effect, $d D_{i} / d F=\left(d D_{i} / d F_{i}\right)\left(d F_{i} /\right.$ $d F$ ), as well as the total effect $d D / d F$, we can use the conclusion above infer that $d F_{i} / d F=$ $\left(d D_{i} / d F\right) /(d D / d F)$.

Having imputed $d F_{i} / d F$, we can now look at the effects of policy on each type of giving. In particular, we can identify how government grants affect fundraising. Let $G$ represent grants. Then our data will allow us to measure $d F / d G$, but not the individual $d F_{i} / d G$. We can, however, impute this value using the expression

$$
\frac{d F_{i}}{d G}=\frac{d F}{d G} \frac{d F_{i}}{d F}
$$

where $d F_{i} / d F$ in the value derived in the prior paragraph.

These calculations will be applied later in the paper when decomposing direct crowding out and indirect crowding out due to reduced fundraising.

\section{Canadian Charity Data}

In Canada, any organization that issues tax receipts to individuals for a donation must become a registered charity with the federal tax authority, the Canada Revenue Agency 
("CRA"). CRA regulations mandate that charities must file an information return annually, within six months of after the end of the charity's fiscal period. Moreover, charities are also required to submit a copy of its own audited financial statement with CRA. Failure to comply with these regulations can result in the charity having its registration status revoked. ${ }^{2}$

Thus, compared to other sources of data on charities (such as US 990 forms), the Canadian charity information returns are richer and more complete given all registered charities must complete the form. The data, however, are collected for administrative and not research purposes. To develop a data set usable for research purposes, we have tried to assess the quality of the data and correct for anomalies when possible. For instance, all values of measures from the returns should be non-negative. In a small number of the observations, a negative value was coded in. In checking a handful of these negative values and in conferring with the data provider, these negative values were converted to positive values. The return should cover a 12 month period. If a charity changes its fiscal period, then a given return may be less or greater than a 12 month period around the time when it switches fiscal periods. We dropped those observations that cover less than 10 months or greater than 14 months to ensure that in a panel data setting observations for a given charity reflect close to a 12 month period. A data appendix that highlights the key anomalies we discovered and addressed when transforming the data to a working data set is available from the authors.

Each registered charity is classified based on their mission statement and other information filed with the CRA. For this study, we use this classification system to focus on those charities that can be considered to be charities involved in the provision of social welfare

\footnotetext{
${ }^{2}$ More information on the filing requirements can be found at www.cra-arc.gc.ca. In speaking with representatives from CRA, in any given year, approximately $95 \%$ of registered charities file their annual returns on time.
} 
and community services. This covers the category codes identified as: care, welfare related (three codes), community related (three codes), recreation, and service clubs (two codes).

Our initial extraction of the data resulted in observations on over 25,000 registered charities for activities from 1992 to 2006. During this period, the information return for the charity changed a few times. The forms from the early periods requested more aggregated information regarding the receipt of revenue from private and government sources. In more recent years, charities have been asked more detailed questions about their revenue from these sources of revenue. We focus our analysis on the following measures (in real terms) from the information returns:

- Any type of revenue from private sources: This includes funding from tax receipted gifts, revenue from fundraising activities, and revenue from other charities. We also analyze these revenue sources separately.

- Government funding: This covers grants received from all levels of government: federal, provincial, and local.

- Fundraising activities: There are two key sources of fundraising activities, namely:

o Fundraising expenditures: This covers expenditures spent on any type of fundraising campaign or general initiative. Charities were required to provide this information in all variations of the information returns filed over the period of study.

o Categorical measures to reflect the type of fundraising activities: in more recent years, charities are asked about their fundraising methods and they include such things as door to door solicitations, anonymous sales of goods, 
mail/phone solicitations, planned giving, corporate campaigns, contracted fundraisers, advertising, and special events.

- The geographic location of the charity, as identified by its postal code. The postal code is important when linking with data on socio-economic characteristics of the neighborhood in which the charity is located and federal parliamentary measures for the political riding (district) in which the charity is located. ${ }^{3}$

An issue we faced early on was whether to include the charities in Canadian territories and in Quebec. The reason for excluding the charities (104) in the territories is that these are remote places and the charity operations may be unlike what is typical in most areas. The charities in Quebec raise a different issue. The majority of francophones in Canada reside in Quebec. Private giving in Quebec is noticeably different than in the rest of Canada. Moreover, the political economy in Quebec and the relationship between the province and the federal government has differed over the last several decades given the province periodically discusses the possibility of separating from Canada. We, therefore, decided to exclude Quebec in our initial analysis.

In addition to gathering measures from the charity information returns, we also use data from two other sources. The second data source is from Statistics Canada and covers measures from the Canadian Censuses conducted during the period under study. In Canada, a census is performed every five years. We use measures from the 1991, 1996, 2001, and 2006 Censuses for the intervening years we linearly interpolate the measures. Our census measures reflect the "neighbourhood" in which the charity is located. Our definition of neighborhood is based on the

\footnotetext{
${ }^{3}$ In some instances we could not link the reported postal code to measures such as the federal riding. In these instances we use the latitude and longitude of the postal code to identify the closest postal code for which the riding information was available. If a latitude and longitude for the postal code was not available (usually because the postal code does not exist), we hand-checked the information for the charity to assign a relevant postal code.
} 
first three characters of the postal code, known as the "forward sortation area" ("FSA"). FSAs are decided by the postal service and are designed to capture an area that can be covered by the postal service. Thus, the postal service takes into account natural and other barriers such as rivers, lakes, and expressways in creating the FSA boundaries. On average, there are 8,000 households in an FSA. As areas expand or contract, the FSA boundaries will change. In assigning charities to FSAs we use the 1996 boundaries. More information on the FSA assignment process is available from the authors.

The third data source is from the Federal Elections Commission. We developed measures to reflect the party affiliation and tenure of the members elected to represent the province in which a charity is located. ${ }^{4}$ We also developed measures to reflect the share of the seats in the provincial parliament held by various parties. ${ }^{5}$

As with other data sets that are based on administrative records, the records for a given charity can be inconsistent over time - or the charity may not be actively engaged in revenue raising. Some of this inconsistency comes from the transformation of the information returns into machine readable code. ${ }^{6}$ Some comes from inconsistent reporting by the charities. Another source of inconsistency relates to the differences in how charities operate. In a recent survey, 30 percent of charities classified as social welfare and community indicated that they are not currently operating (providing goods and services) despite their still filing information returns to CRA. Given we cannot hand-check every return of every charity, we explain below the

\footnotetext{
${ }^{4}$ We also developed measures of party affiliation and tenure for the federal election district in which the charity is located. These measures, however, were not robust in our empirical analysis.

${ }^{5}$ In Canada, across the provinces there are several political parties that are well represented. Thus, unlike the US, there is more than a two-party system. The dominant political parties during the period under study are the Liberal Party, the Conservative Party, the New Democrat Party, and the Bloc Quebecois. ${ }^{6}$ Our understanding is that most returns were scanned into a machine readable code. These scans were done once and were not necessarily checked for accuracy.
} 
judgment calls we made to ensure a reasonably accurate and relevant set of charities for our analysis. $^{7}$ In section $4 \mathrm{E}$ we test the sensitivity of our results to the core data exclusion rules.

- Charities that indicate in all years that they only operate nationwide were dropped (411 charities, 3921 observations)

- Charities that never report a positive level of private giving are dropped (888 charities, 4939 observations)

- Annual observations for which there is no reporting of either private giving or government funding are dropped (7484 observations).

- No evidence of fundraising activity. As indicated above, we observe fundraising activity through both reported fundraising expenditures (all years) and types of fundraising activities undertaken by the charity (post 1996). If a charity never reports fundraising expenditures and never reports fundraising activities, it is dropped (2391 charities, 21895 observations).

- Charities with fundraising expenditures that are greater than all reported private giving and are in the top $1 \%$ of the distribution based on the difference between fundraising expenditures and private giving for one or more years (621 charities, 8944 observations).

- Charities that have fewer than 3 years of observations over the period are dropped (1247 charities, 1946 observations).

- There are some charities that do not always report fundraising activity. We include those charities if at least $40 \%$ of their observations suggest evidence of fundraising activity (dropping 4349 charities, 48030 observations).

\footnotetext{
${ }^{7}$ Charities/observations were dropped sequentially. Thus, some charities may be excluded for more than one of the listed criteria.
} 
- As in other research we have done, the results are sensitive to the inclusion of charities with very big revenues. As we discovered, there are some revenues that look so large they are likely incorrectly reported. If a charity reports its values using dollars AND cents, when the forms ask only for dollars, then when scanned, the decimal point can get ignored, resulting in the revenues (and other measures) being reported at 100 times the real amounts. We therefore exclude those charities whose total revenues are in the top $15 \%$ of total revenues for one or more years (1216 charities, 16002 observations).

After these exclusions, we are left with 6,554 charities and 68,146 observations that are studied. In Panel A of Table 1, we report the summary statistics for our key measures. All dollars amounts have been adjusted to 2001 dollars. Starting first with private giving, overall, average private funding per charity is approximately $\$ 40,000$ over the sample period. There is a fair bit of variation in this funding - the maximum annual private giving is $\$ 718,000$. One reason for the low average private funding is that all charities, regardless of size, must file an information return. In the United States, smaller charities do not have to file the equivalent form. Across sources of private funding, more funding, on average, is received as a tax-receipted gift than as revenue from a fundraising event (for which a tax-receipt is not issued). Similar to the United States, the average level of government funding is higher than the average level of private funding. The average level of funding is $\$ 57,000$ - the maximum level of government funding reported is $\$ 706,000$. The average level of fundraising expenditures is more than $\$ 7,000$.

\section{Estimation and Results}

As in previous research, we are interested in estimating three relationships: (1) the effect of government funding on private funding, controlling for fund-raising; (2) the effect of fund- 
raising on private funding, controlling for government funding; (3) the effect of government funding on fund-raising. The estimation challenges include controlling for endogeneity from unobserved characteristics or events that cause donations, grants, and fund-raising to be correlated. We also have to be concerned with the specification issues and what might be captured in the error term, suggesting that a three stage least squares technique is not appropriate.

We, therefore, estimate the following three equations:

$$
\begin{aligned}
& \text { Private Revenue }_{i s t}=\alpha^{1}{ }_{i}+\lambda^{1}{ }_{t}+A \cdot \text { GovtFunds }_{i s t}+\text { Controls }_{i s t}\left(\omega^{1}+\varepsilon^{1}{ }_{\text {ict }}\right. \\
& \text { Private Revenue }_{i s t}=\alpha_{i}^{2}+\lambda^{2}{ }_{t}+B \cdot \text { Fundraising }_{i s t}+\text { Controls }_{i s t} \omega^{2}+\varepsilon^{2}{ }_{\text {ict }} \\
& \text { Fundraising }_{i s t}=\rho_{i}+\varphi_{t}+C \cdot \text { GovtFunds }_{\text {ist }}+\text { Controls }_{\text {ist }} \kappa+\eta_{\text {ict }}
\end{aligned}
$$

In equation (1) we are estimating the total effect of a change in government funding on private giving to the charity. The coefficient "A" represents total crowd-out. In equation (2) we estimate the effect of a change in fundraising expenditures on private giving. If a charity is operating optimally, we would expect the coefficient " $\mathrm{B}$ " to equal one - that on the margin, the last dollar spent earns an extra dollar of funding. An amount greater than one is reflective of general expectations about fund-raising, that charities will spend less on fundraising than would be optimal under standard economic theory. In equation (3), we estimate the effect of a change in government funding on fund-raising efforts by the charity. Our analysis focuses first on the

results from each of these specifications. Second, however, we will use the estimations to decompose total crowd-out into the components attributable to a change in private giving and to a change in charity fund-raising.

\section{A. Total crowd-out effect of government grants on private giving}

In panel A of Table 2, we focus first on the total crowd-out effect. The richness of the Canadian data allows us to investigate both the effect of a change in government funding on 
overall private giving as well as on its components: tax-receipted gifts, revenue directly from fundraising, and revenue received from other charities. In all specifications we include charity fixed effects and year dummies to control for time-invariant characteristics of the charities and macro level shocks that affect all charities, respectively. In addition, we include several types of controls. First, we include a charity specific time trend and the square of this trend. These measures are designed to capture changes that may be going on at the charity that could be correlated with both private and public revenue sources. ${ }^{8}$ Second, we include the following census characteristics based on the FSA in which the charity is located: average household income and the square of this term (in real terms), total population, the share of the total population that: are less than 19 years, between 55 and 64 years of age, over 65 years of age, are identified with any visible minority group, have moved within the last five years, and that have immigrated to Canada since 1981. These measures are designed to capture time-varying changes in the neighborhood in which the charity is located. There is also variation captured if the charity moves FSAs over the sample period. Third, we include provincial level measures to capture the political party affiliations of the members in the provincial parliament. We use the share of members in the Conservative party as the omitted measure and include measures for the Liberal party, the New Democrat Party, and other parties. These political measures capture timevarying effects of changes in the political leadership that are correlated with public and private donations.

\footnotetext{
${ }^{8}$ Alternatively one could try to include alternative sources of revenues, expenditures, assets, and/or liabilities of the charities as control measures. These measures, however, are arguably endogenous and would potentially bias the coefficient on the measure of interest (e.g. government grants). We, therefore, opt to use a more global measure to capture trends in the charity. The trend measure starts at 0 for the first year in which we observe a charity and increased by one unit per year.
} 
In column 1, we report the results using a standard OLS fixed effects specification. Like many other papers, the coefficient is small in magnitude and does not suggest any crowd-out. This is likely attributable to endogeneity and omitted variable bias.

Our preferred set of specifications, thus, is one where we control for these biases by employing a two-stage least squares specification (2SLS). We use the limited information maximum likelihood (LIML) variation of the 2SLS specification as LIML is generally considered superior in terms of issues related to concerns about weak instruments (see, e.g., Wooldridge, 2002, Bound, et al, 1995). The difficulty with the 2SLS specification is to identify a set of measures that explain government grants but do not directly explain the dependent variable, private giving. Given that government grants also explain fundraising expenditures and there is a relationship between fundraising expenditures and private giving, it is also important to find instruments that also do not directly explain fundraising expenditures. We explored two types of instruments. The first type is related to the federal political factors that affect the allocation of government funding to programs that allow for the funding of charities. If the composition of the parliament changes with respect to such things as party affiliation or tenure, funding to programs that support government grants is likely to change. An underlying issue, however, is that donors are also voters. This is why our control measures include time-varying characteristics of provincial parliament membership. Thus, simply using measures of federal riding party affiliation and/or tenure of the member representing the riding may not be sufficiently exogenous to make them good instruments. Moreover, given we are including charity fixed effects and year effects, there may not be sufficient within charity time variation in riding level measures to be a strong instrument. 
We explored several possible instruments that exploit information about the party affiliation and tenure of members in federal parliament. The two strongest instruments are those at the provincial level. The first instrument is one that links the tenure (by month) of the federal parliament members to the party in power at the provincial government. In Canada, many federal funds end up being distributed through provincial or local levels (see, e.g., http://etatscanadiens-canadiangovernments.enap.ca for a discussion of transfers from the federal government to lower levels of government). It is not uncommon for lower levels of government to encourage the federal government for more resources. We hypothesize that if the senior federal members of parliament in a province are affiliated with the majority party in the provincial parliament, this may affect the distribution of funds. More generally, our second instrument captures the total tenure of the members of the federal parliament representing the province in which the charity is located. The sign of the direction of the funding to charities for these two instruments, however, is unclear given more senior members of parliament may or may not be rent-seeking.

For the first instrument, the key sources of time variation is tied to (a) timing of federal elections, (b) timing of provincial elections, and, to a lesser extent, (c) by-elections to fill vacant seats in federal elections. In Canada, federal elections are not prescribed to be in a given month and year as they are in the United States and elsewhere. The party in power can choose when to hold an election provided it is held within five years of the last election. Provincially, provinces followed this same pattern until 2001. Since 2001, seven provinces and one territory have adopted fixed election dates. For the period of our study, however, only British Columbia (2001) Ontario (2004), and Newfoundland and Labrador (2004) implemented fixed election dates. We explore two measures: (a) the total tenure of members of the federal parliament that are affiliated 
with the party in power in the provincial parliament, and (b) the tenure of members in the federal parliament for the province. The second type of instrument is one that exploits the level of government funding that is made available to charities within the province. The hypothesis for this instrument is that the level of funding available to any given charity will be both a function of the number of charities that might receive the funding and the level of funding being allocated. For all registered charities within a province that are not religious and are not foundations, we created a measure that reflects the total government grants reported. This measure includes charities not studied, such as those in the health, education, historical, cultural, and environmental sectors.

Using instruments at a provincial level, however, does raise an issue about the precision of these instruments given the core measures are at a local/charity level. There is the potential that in the first stage regression, the standard errors are too low given with a charity fixed effect specification, the standard errors are clustered at the charity and not provincial level. With the charity fixed effects, however, we are controlling for time-invariant differences across charities in the same province. The concern, thus, is limited to one that is focused on potential correlations across charities in a province that are time-varying over the sample period. To help control for this type of correlation, we include in our instrument set a measure at the local level that still satisfies the tests for strength in instruments and over-identification. Our local measure is one that interacts a dummy variable that is equal to one if the member of the federal parliament representing the area in which the charity is located is affiliated with the party in power in the provincial parliament with the measure that captures the total tenure of members in the federal parliament that are affiliated with the party in power in the provincial parliament. 
In Panel C of Table 2, we report the coefficients and F-statistics for three pairings of the instruments in the first stage regression. ${ }^{9}$ In column 2, we use the measure that reflects the tenure of federal parliament members affiliated with the majority party in provincial government, its interaction with the local measure of if the federal member for the charity's riding is affiliated with the party in power at the provincial level, and the total government grants reported by nonreligious charities. The coefficient on the provincial political measure is negative suggesting that having more members with seniority affiliated with the political power in majority in the provincial parliament decreases the level of government funding. The coefficient on the local political measure is positive, but imprecisely measured. The coefficient on the government funding to non-religious charities is also negative. Whether the sign on these coefficients makes sense is unclear. The estimation controls for charity fixed effects, macro level year effects, charity year trends, and political and socio-economic measures. The F-statistic on the two instruments is 14.55 .

In column 3, Panel C, we report the first stage results if we pair the two provincial level political measures as instruments and include the local political measure. The coefficients on all three measures are individually significant and the F-statistic on the pairing is 10.21. And, in column 4, we group the political measure for the total tenure of the federal members of parliament, the local political measure, and the government funding to non-religious charities. All three coefficients are individually significant and the F-statistic for the pairing is 13.81. All of these F-statistics meet accepted standards for strength of instruments in predicting the endogenous measure (government grants).

\footnotetext{
${ }^{9}$ The estimations of from the first and second stage equations if the three possible instruments are used individually are reported in Appendix Table 1.
} 
Under the 2SLS/LIML specifications, panel A of Table 2, the results suggest there is complete crowd-out of private giving. The point estimates range -0.95 to -1.07 depending on the set of instruments used. All coefficients are significant at a p-value of less than 5 percent. For these three sets of instruments, we can test for whether the instruments have any predictive power for private giving through the use of the Sargan test of over-identifying restrictions. This test produces a chi-square statistic with degrees of freedom equal to the number of instruments less the number of endogenous measures (one). A low statistic (high p-value) suggests the instruments, on their own, do not explain private giving. The over-identification test is satisfied for all three groups of instruments.

The level of crowd-out measured is one of the highest levels we have observed empirically. A benefit to our data is that we can explore whether the crowd-out differs based on the source of the private giving. In columns 5-7, we breakout the crowd-out for tax-receipted gifts, revenues from fundraising, and gifts from other charities, respectively. By definition, we should expect the level of crowd-out across these three sources of revenue to sum to close to dollar for dollar crowd out. To save space, we report the results from the first set of instruments.

Tax-receipted gifts are the donations for which a donor can use her charitable giving as a credit against income tax liability. The coefficient on government grants for this measure of giving is small and insignificant for instrument set $\# 1 .^{10}$ Revenues from fundraising include any revenues associated with a fundraising activity for which a tax-receipt is not issued. The crowdout associated with these revenues is quite high, 54 cents for every dollar of government grants. The crowd-out associated with revenues from other charities is approximately 36 cents for every dollar of government grants.

\footnotetext{
${ }^{10}$ If we exclude the local political measure and use the remaining instruments from instrument group 3 , the coefficient is -0.23 and statistically significant.
} 


\section{B. Effect of Government Grants on Fundraising Expenditures}

In Panel B of Table 2, we report the results of the specification where fundraising expenditures are the dependent variable. The results for this specification are not as robust as the results for the specifications where private giving is the dependent variable. The point estimates range from -0.09 to -0.16 but only the specification for instrument pairing \#1 is statistically significant at less than a $5 \%$ level. One of the difficulties with finding instruments for the government funding measure is that they must both explain government funding but not have direct effects on either fundraising expenditures or private giving. Given the importance of finding instruments that work well for both dependent variables, our preferred specification uses instrument set \#1. The results suggest that a dollar increase in government grants reduces fundraising expenditures by 16 cents.

\section{Effect of Fundraising on Private Giving}

The final equation to be estimated is the effect of fundraising expenditures on private giving, which we report in Table 3. As with the other estimations, we include charity fixed effects, year dummies, and controls for time varying changes to the charity, the neighborhood in which the charity is located, and the partisanship of the provincial parliament. In column 1 we report the estimates under an OLS specification. This point estimate suggests that an additional dollar of fundraising brings in approximately one dollar of private giving.

Given that fundraising expenditures also react to changes in government funding, however, we must also find exogenous variation in fundraising expenditures that is also exogenous to changes in government funding and not directly correlated with changes in private giving. An advantage to the Canadian data is that in later years (starting in 1996), charities must identify the type of fundraising activity they undertake. Within the charitable sector, there is the belief that 
different solicitation methods provide different returns to fundraising. Thus, to the extent this is true, using measures that reflect the nature of the fundraising activity should help to identify the exogenous variation in fundraising expenditures. On the return, the charity simply checks a box for the various types of fundraising activities, thus they represent categorical measures with a value of zero or one. We grouped a subset of these activities into the following categories:

Category 1: Fundraising through door to door solications and through anonymous sales (e.g. candy bars on the street, poppies for Remembrance day)

Category 2: Fundraising through mail and telephone solicitations

Category 3: Fundraising through corporate campaigns and the hiring of contracted fundraisers.

In our analysis, we found that using these groups provided the most robust and stable results. While there are other types of fundraising methods identified on the forms, we found these other measures did not satisfy issues concerning the strength of the measures and/or over-identification tests.

In columns 2-4 we report the results for different combinations of these three instruments. ${ }^{11}$ In Panel B we report the coefficients on the instruments and the F-statistic from the first stage regression. Across all three specifications, the instruments are individually statistically significant and the F-statistic for the combination of instruments exceeds accepted standards. Across the three groupings, the results are similar, suggesting that an additional dollar of fundraising brings in between $\$ 4.60$ and $\$ 5.10$ in private giving. These estimates are analogous to those reported in Andreoni and Payne (2011) using US data. As explained in that paper, the coefficient is not intuitive under standard economic theory. Given the scrutiny charities often

\footnotetext{
${ }^{11}$ In Appendix Table 2 we report the results when each of these instruments are used individually.
} 
face if they report high values of expenditures not directly tied to the provision of charitable services, it is not surprising that they do not follow standard economic theory.

The coefficient varies across our three types of private giving. In columns 5a-7b, we report the results for the three types of private giving, using first two sets of instruments. ${ }^{12}$ When using tax-receipted gifts as the dependent variable, the results suggest that an additional dollar of fundraising raises between $\$ 2.10$ and $\$ 2.70$ of this type of revenue. For revenue from fundraising, the estimates suggest an extra dollar of fundraising increases this type of revenue between $\$ 1$ and $\$ 1.85$. Whereas for revenue from other charities/foundations, an additional dollar of fundraising expenditures increases the revenues by close to 50 cents. As pointed out above, the difficulty when decomposing the effects of fundraising expenditures on the components of private giving is that we do not know the extent to which fundraising expenditures were directed at these specific components. We expect there is a spillover effect across the three categories. For example, if one hosts a gala dinner, the advertisements of the gala dinner provide information about the charity to participants and non-participants of the dinner. Thus the raising of public awareness could also promote revenues in the form of taxreceipted gifts to the charity.

\section{Decomposing Crowd-out}

To what extent is crowd-out attributable to a change in donor behavior and to what extent is it attributable to a change in charity behavior? In table 4, we present the decomposition based on our preferred specifications. In Panel A, we report the coefficients from the estimations reported in Tables 2 and 3 using Instrument Set \#1 in all cases. We also report the imputed values of $d F_{i} / d F, d D_{i} / d F_{i}$, and $d F_{i} / d G$ needed for policy analysis.

\footnotetext{
${ }^{12}$ For all three private giving measures, the results for instrument set \#3 are similar to those reported for instrument set \#2.
} 
In Panel B, we present the decomposition of crowd-out using the imputed values. Direct crowd-out is the result of private funding directly altering their level of giving given the level of government funding. Indirect crowd-out is the result of the charity reducing its fundraising efforts as a result of the government funding. In column 1 we start with the overall level of private giving. Here the total crowd-out is estimated as close to dollar for dollar. The results suggest that, overall, the bulk of crowd-out is attributable to a change in charity fundraising. Only 30 percent of the crowd-out is attributable to change in total private giving. In Panel C, we decompose the crowd-out after adding back in the savings from reduced fundraising. The bulk of the crowd-out, however, is still attributable to a change in charity behavior.

In columns 2-4, we further decompose the crowd-out based on the type of private giving. Starting first with tax-receipted gifts (column 2), recall the total level of crowd-out is close to zero. This suggests that for tax-receipted gifts, given charities reduce their fundraising efforts with government grants, there is a crowding in of tax-receipted gifts. There appears to be a slight increase in tax-receipted gifts (about 34 cents for a dollar of government funding). Thus, when focusing on tax-receipted gifts, because charities decrease their fundraising, there is a high amount of indirect crowding out - countering the crowding in attributable to donor behavior.

Next, when looking at revenues from fundraising activities (column 3), the measured crowdout is mostly attributable to direct crowd-out. Approximately $31 \%$ of the crowd-out is attributable to indirect crowd-out. When we factor in the savings from reduced fundraising (Panel C), close to three-quarters of the crowd-out is attributable to the direct effect.

Finally, when looking at revenues from other charities (column 4), the measured crowd-out is mostly (78\%) attributable to the direct effect. When we factor in the savings from reduced fundraising (Panel C), more than $80 \%$ of the crowd-out is attributable to the direct effect. 
Decomposing the private giving into its three core components reveals that the impact of government funding is not the same across all types of giving. If we focus solely on direct donations (tax-receipted gifts), all of the crowd-out is attributable to charity behavior. The results suggest that individual donors do not decrease their donations unless the ask to give decreases. Not surprisingly, if fundraising expenditures decline, then there is a big direct effect on the revenue from fundraising, providing further support that charities may view fundraising as a necessary evil. The greatest direct crowd-out is observed by the gifts from other charities and foundations. These likely are the most informed sources of revenues. The results suggest other charities and foundations may view government funding as a direct substitute for their own contributions.

\section{E. Robustness Checks}

In Section 3 we walked through the various assumptions and decisions we made to develop the data set used in our analysis. In this section, we explore the sensitivity of our results if we change some of these decisions. The results are reported in Table 5. For the most part the estimates for the effect of government funding on private giving and for the effect of fundraising on private giving do not change. The estimates that are sensitive are those for the effect of government funding on fundraising expenditures. For the most part, however, the coefficient on government funding is significant at least at a $10 \%$ level.

In the last column of Table 5 we report the results if we were to include the charities that are located in Quebec. As stated earlier, we excluded these charities because they operate in an environment that is likely different than in the other provinces due to the political economy of Quebec and the differences in population in Quebec. Including Quebec results in a lower overall 
crowd-out, 73 cents versus one dollar, imprecisely measured effects of government funding on fundraising, and a higher effect of fundraising on private giving, $\$ 5.70$ versus $\$ 5.10$.

\section{Conclusion}

This question of government crowd out of private donations is one of the oldest and most important public economics issues. While it has been studied extensively in the US, this study is, we believe, is the first of its kind for Canada. The analysis here followed that of Andreoni and Payne (2011, 2003). Using US data, they found that, in total, \$1000 government grants crowd out is close to $\$ 750$ in other donations—crowding out 75 percent-but most of this crowding out is attributable to reduced fundraising by the charity.

Here we find similar results, but the greater quality and precision of the Canadian data provides further important insights into the market for charity. First, estimates of gross crowding out exceed 100 percent, of which 77 percent can be attributed to reduced fundraising by the charities. Crowd-out, however, varies dramatically across the different sources of private revenue. Direct giving by individuals (tax-receipted gifts) is only reduced if the charity reduces its fundraising — crowding out of gifts from individuals is fully the result of reduced fundraising. In fact, the government grants have a small effect of crowding-in individual donors, which is consistent with a view that individuals are either unaware of changes in government grants, or are using them as signals of the quality of the charity. Accounting for both the crowding-in of donors and the reduction in fundraising efforts, revenue from direct donations remains constant on average. By contrast, donations from other charities or foundations, which come from the source that is perhaps best informed about both the finances and the quality of the charity, is the very responsive to government grants: each $\$ 1000$ in grants reduces revenue from other charities 
by $\$ 280$, which accounts for 78 percent of crowding out from this source. Turning to the third source, revenue from special fundraising programs (revenue from fundraising), such as galas or sponsorships, we find the biggest marginal reductions in donations. A \$1000 grant reduces revenues from special events by $\$ 540$.

Taken together we get something of a different picture than was allowed in the US data. Each $\$ 1000$ in grants reduces revenue from other sources by about $\$ 1000$, but this total crowding out is not due to declining individual donations, but rather due to reduced revenue from foundations and other charities, and from holding fewer fundraising events. While the overall finding in both the US and Canada are the same-that crowding out is high, but mostly attributable to direct reductions in fundraising activities of the charities themselves-the explanation for this effect is more precise with the current analysis.

It is important to keep in mind when interpreting the analysis of these data that it is capturing behavior at a very high level. Many of the details of how charities are run cannot be seen or described here. In particular, one must be careful to remember that charities are in long term relationships with their contributors, be they individuals, foundations, or the government. It is well known in fundraising communities that getting the first contribution from an individual is the hardest, and obtaining repeat donations is far easier. If this is true, then the assumption that within a given year the charity allocates its fundraising across revenue sources to equalize the marginal contributions will be erroneous—we would need to equate the marginal expected present value of donations instead. It is difficult, however, to know how this would affect our conclusions, if at all.

It is also important to note that reductions in donations to one charity do not necessarily mean a reduction in charitable giving overall. In fact, our results allow us to characterize an 
upper bound on this amount. In particular, one third of all the crowding out is donations from foundations and other institutions. This money will likely stay within the charitable sector since it represents money that has already been donated, but just not allocated to the providers of final charitable goods and services. Hence, even though we estimate a grant to a particular charity reduces contributions to that charity nearly dollar for dollar, at most two thirds of the dollars lost to this charity are lost to the charitable sector overall. 


\section{References}

Andreoni, James (1998) "Toward a theory of charitable fundraising." Journal of Political Economy 106:1186-1213(December)

Andreoni, James (2006). Philanthropy. In:Kolm,S.-C., Mercier Ythier, J. (Eds.), Handbook of Giving, Reciprocity and Altruism. North Holland, Amsterdam, pp.1201-1269.

Andreoni, James (2007) "Giving gifts to groups: how altruism depends on the number of recipients” Journal of Public Economics 91:1731-1749 (September)

Andreoni, James, Payne, A. Abigail (2011) "Is crowding out due entirely to fundraising? Evidence from a panel of charities.” Journal of Public Economics 95(5-6):334-343.

Andreoni, James, Payne, A. Abigail (2003) "Do government grants to private charities crowd out giving or fundraising? The American Economic Review 93:792-812 (June)

Andreoni, James, Rao, Justin M., (2011) "The Power of Asking: How Communication Affects Selfishness, Empathy, and Altruism.” Journal of Public Economics, 95: 513-520.

Andreoni, James, Justin M. Rao, and Hannah Trachtman, (2011) “Avoiding the Ask: A Field Experiment on Altruism, Empathy, and Charitable Giving.” Working paper.

Bergstrom, Theodore, Lawrence, Blume, Hal, Varian (1986) "On the private provision of public goods.” Journal of Public Economics 29:25-49 (February)

Bound, John, Jaeger, David A., Baker, Regina M. (1995) "Problems with Instrumental Variables Estimation When the Correlation Between the Instruments and the Endogenous Explanatory Variables is Weak." Journal of the American Statistical Association, 90 (430):443-450.

Correa, Alvaro and Huseyin Yildirim (2011) “A theory of charitable fundraising with costly solicitation." Working paper

Meer, Jonathan and Harvey S. Rosen (2011)“The ABCs of charitable giving.“ Journal of Public Economics 95(5-6): 363-371

Okten, C and B Weisbrod. (2000) "Determinants of Donations in Private Nonprofit Markets,” Journal of Public Economics, 75: 255-272.

Rose-Ackerman, Susan (1982) “Charitable giving and `excessive; fundraising." Quarterly Journal of Economics 97:195-912

Vesterlund, Lise (2003). "Informational value of sequential fundraising." Journal of Public Economics 87: 627-657

Warr, P.G. (1982) "Pareto optimal redistribution and private charity." Journal of Public Economics 19:131-138 (October).

Wooldridge, Jeffrey M. (2002) Econometric Analysis of Cross Section and Panel Data MIT Press, Cambridge, MA 


\begin{tabular}{|c|c|c|c|c|}
\hline Panel A: Summary Statistics for Preferred Sample & $\begin{array}{c}\text { \# of } \\
\text { Observations }\end{array}$ & Mean & $\begin{array}{l}\text { Standard } \\
\text { Deviation }\end{array}$ & $\begin{array}{c}\text { Maximu } \\
\mathrm{m}\end{array}$ \\
\hline Any Type of Donation/Revenue From Fundraising (/1000) & 68146 & 39.66 & $(68.14)$ & 718.52 \\
\hline Tax Receipted Gifts (/1000) & 68146 & 18.67 & $(42.95)$ & 697.68 \\
\hline Revenue from Fundraising (/1000) & 68146 & 11.73 & (31.31) & 713.42 \\
\hline Revenue from Other Charities (/1000) & 68146 & 4.96 & $(20.44)$ & 550.68 \\
\hline Government Funding (/1000) & 68146 & 47.61 & (96.94) & 706.06 \\
\hline Fundraising Expenditures (/1000) & 68146 & 7.29 & $(19.86)$ & 546.88 \\
\hline \multicolumn{5}{|l|}{ Panel B: Summary Statistics for Measures Used as Instruments In 2SLS specification } \\
\hline $\begin{array}{l}\text { Total tenure of members in federal parliament affiliated with majority political party in the } \\
\text { Provincial Parliament (/1000) }\end{array}$ & 68146 & 1.33 & $(2.92)$ & 13.10 \\
\hline $\begin{array}{l}\text { Total tenure of federal parliament members affiliated with the provincial parliament party ir } \\
* \text { If local member's political party is same as provincial parilaiment party in power }(/ 1000)\end{array}$ & 68146 & 0.86 & $(2.66)$ & \\
\hline Total Government Funding to Non-Religious Charities in Province $(/ 1,000,000)$ & 68146 & 2.09 & $(1.02)$ & 6.21 \\
\hline Total tenure of members of federal parliament (months) within the province (/1000) & 68146 & 4.50 & $(4.02)$ & 13.49 \\
\hline \multicolumn{5}{|l|}{ Instruments for Fundraising Expenditures } \\
\hline Fundraising through door to door, anonymous sales & 54326 & 0.46 & $(0.63)$ & 3.00 \\
\hline Fundraising through mail and phone solicitations & 54326 & 0.19 & $(0.44)$ & 2.00 \\
\hline Fundraising through corporate campaigns, contracted fundraisers & 54326 & 0.16 & $(0.45)$ & 3.00 \\
\hline
\end{tabular}

Notes:

revenue from donations/fundraising include: tax-receipted gifts, amounts received from other charities, other gifts, and revenue from fundraising No sign of fundraising effort includes zero fundraising expenditures AND no reporting of different types of fundraising campaigns (0/1 measures) 


\section{Panel A: Effect of Government Funding on Private Giving}

Government Funding

\section{Instrument Set for Government Funding}

Over-Identification Test (chi-square statistic)

(p-value)

\section{Panel B: Effect of Government Funding on Fundraising Expenditures} Government Funding

\section{Instrument Set for Government Funding \\ Over-Identification Test (chi-square statistic) \\ (p-value)}

\section{Panel C: First Stage Results (Government Grants)}

F-Statistic on Instruments

(p-value)

Coefficients on Instruments

Total tenure of federal parliament members affiliated with the provincial parliament party in power

Total tenure of federal parliament members affiliated with the provincial parliament party in power * If local member's political party is same as provincial parilaiment party in power

Total tenure of members of federal parliament

Total Government Funding to Non-Religious Charities in Province (/1000)

\section{\# of Observations}

\# of Charities
Total Private Giving

$\begin{array}{ccc}(1) & (2) & (3) \\ 0.01 & \mathbf{- 1 . 0 7} & \mathbf{- 0 . 9 5} \\ (0.007) & (0.26) & (0.27)\end{array}$

Tax

Revenue

Receipted Revenue from from Othe

Gifts* Fundraising Charities

(0.007)

(4)

$-1.03$

(5a) (6a) (7a)

$-0.09 \quad-\mathbf{0 . 5 4} \quad \mathbf{- 0 . 3 6}$

$(0.10) \quad(0.15) \quad(0.09)$

$\begin{array}{cccccc}\# 1 & \# 2 & \# 3 & \# 1 & \# 1 & \# 1 \\ 0.52 & 0.21 & 1.13 & 1.16 & 0.72 & 2.24 \\ (0.770) & (0.902) & (0.570) & (0.560) & (0.697) & (0.326)\end{array}$

Notes: Robust and clustered standard errors reported in parentheses unless otherwise stated. Coefficients in bold $\mathrm{p}<.05$, coefficients in bold \& italics $\mathrm{p}<.10$. All regressions include the following covariates: charity fixed effects, charity specific time trend and square of charity specific time trend, year dummy variables The following measures at the neighbourhood (forward sortation area) level: average household income, square of average household income, total population share of population in the following age groups: less than 19, 55 to 64, 65 and greater, share of population that has moved in the last five years, share of the population that immigrated since 1981, and share of the population that is a visible minority

The following measures at the provincial level: share of the seats in the provincial parliament that are held by liberals, the new democratic party, and parties other than conservatives. 


\section{Panel A: Effect of Fundraising on Private Giving}

Fundraising expenditures

\section{Instrument Set for Fundraising}

Over-Identification Test (chi-square statistic)

(p-value)

\section{Panel B: First Stage Results (Fundraising)}

F-Statistic on Instruments

(p-value)

Coefficients on Instruments

Fundraising through door to door, anonymous sales

Fundraising through mail and phone solicitations

Fundraising through corporate campaigns, contracted fundraisers

\section{\# of Observations}

\# of Charities
Total Private Giving
(1)

1.01

$(0.03)$
(2)

5.06

(0.81)

(3)

4.63

(0.64)

(4)

4.79

(0.70)

$\begin{array}{ccc}\# 1 & \# 2 & \# 3 \\ 0.134 & 0.01 & 0.38 \\ (0.714) & (0.919) & (0.540)\end{array}$

Tax

Gifts

(5a)

2.69

(0.53)

$\# 1$
2.45

(0.117)

$\# 1$

15.40

(0.00)

\#2

25.61

$(0.00)$

\#3

20.23

(0.00)

\section{$\begin{array}{ll}0.63 & 0.77\end{array}$}

(0.18) (0.19)

1.63

(0.38)

(0.19)

\subsection{1}

(0.37)

2.27

(0.39)

$(0.38)$

68,146

6,554

$\begin{array}{cc}\text { Tax } & \text { Revenue } \\ \text { Receipted } & \text { From }\end{array}$

Gifts Fundraising

(5b) (6a)

(6a)
1.03

2.10

(0.36)

$(0.24)$

$\# 2$
0.56
$(0.454)$

$\# 1$
0.78
$(0.376)$

1.51

$(0.220)$

0.11

(0.739)

0.05
$(0.817)$

Notes: Robust and clustered standard errors reported in parentheses unless otherwise stated. Coefficients in bold $\mathrm{p}<.05$, coefficients in bold \& italics $\mathrm{p}<.10$. All regressions include the following covariates: charity fixed effects, charity specific time trend and square of charity specific time trend, year dummy variables The following measures at the neighbourhood (forward sortation area) level: average household income, square of average household income, total population share of population in the following age groups: less than 19, 55 to 64, 65 and greater, share of population that has moved in the last five years, share of the population that immigrated since 1981, and share of the population that is a visible minority

The following measures at the provincial level: share of the seats in the provincial parliament that are held by liberals, the new democratic party, and parties other than conservatives. 


\section{Panel A: Summary of Estimations}

A: Effect of Government on Donations (dD / dG) [Table 2]

B: Effect of Fundraising on Donations (dD / dF) [Table 3]

C: Effect of Government on Fundraising (dF / dG) [Table 2]

\section{Imputed values for Fundraising}

Allocation of Fundraising: $d F \_\mathrm{i} / \mathrm{dF}=\left(\mathrm{dD} \_\mathrm{i} / \mathrm{dF}\right) /(\mathrm{dD} / \mathrm{dF})^{* *}$

B': Effect of Fundraising on Donations $\left(\mathrm{dD} \_\mathrm{i} / \mathrm{dF} \_\mathrm{i}=\mathrm{dD} / \mathrm{dF}\right)$

$C^{\prime}$ : Effect of Government on Fundraising $\left(\mathrm{dF} \_\mathrm{i} / \mathrm{dG}=(\mathrm{dF} / \mathrm{dG}) *\left(\mathrm{dF} \_\mathrm{i} / \mathrm{dF}\right)\right)$

\section{Panel B: Decomposition of Crowd-Out}

Total Crowd-Out (A)

Direct Crowd-Out $\left(\mathrm{A}-\mathrm{B}^{\prime *} \mathrm{C}^{\prime}\right)$

$\%$ of Total Crowd-Out

Indirect Crowd-Out $\left(\mathrm{B}^{\prime *} \mathrm{C}^{\prime}\right)$

$\%$ of Total Crowd-Out

\section{Panel C: Decomposition of Crowd-out based on spending (adding back in savings from fundraising)}

Total Crowd-Out (A-C')

Direct Crowd-Out (A-B'*C')

$\%$ of Total Crowd-Out

Indirect Crowd-Out ( $\left.\mathrm{B}^{\prime *} \mathrm{C}^{\prime}-\mathrm{C}^{\prime}\right)$

$\%$ of Total Crowd-Out
$-1.07$

5.06

$-0.16$

1.00

5.06

$-0.16$

-0.90
-0.25

$27.4 \%$

Tax- Revenue Revenue Receipted From from Gifts Fundrais Other

$-0.09$

2.69

2.69
-0.16 ing

(3)

$-0.54$

Charities

$-0.54 \quad-0.36$

1.03

0.49

$-0.16$

$-0.16$

$-0.16$

$\begin{array}{cccc}-1.07 & -0.09 & -0.54 & -0.36 \\ & & & \\ -0.25 & 0.34 & -0.37 & -0.28 \\ 23.2 \% & & 69.1 \% & 77.9 \% \\ & & & \\ -0.82 & -0.44 & -0.17 & -0.08 \\ 76.8 \% & & 30.9 \% & 22.1 \%\end{array}$

$\begin{array}{ccc}0.53 & 0.20 & 0.10 \\ 5.06 & 5.06 & 5.06 \\ -0.09 & -0.03 & -0.02\end{array}$

$\begin{array}{cccc}-0.66 & -0.35 & -0.13 & -0.06 \\ 72.6 \% & & 26.4 \% & 18.6 \%\end{array}$


Drop if Never Receive Exclude years before Exclude if in top 2\% of Keep regardless of 1994 Fundraising - Private Extreme Differences in Exclude if $45 \%$ or more of the

Exclude if $35 \%$ o more of the

Exclude if in top 10\% Exclude if in top 5\% of INCLUDE QUEBEC Fundraising - Private observations have no observations have no Giving evidence of fundraising evidence of fundraising

Panel A: Effect of Government Funding on Private Giving

Government Funding

Instrument Set for Government Funding

F-Statistic on Instruments

(p-value)

Over-Identification Test (chi-square statistic)

(p-value)

Panel B: Effect of Government Funding on Fundraising Expenditures

Government Funding

Over-Identification Test (chi-square statistic) (p-value)

\section{Panel C: Effect of Fundraising on Privat} Giving

Fundraising Expenditures

\section{Instrument Set for Fundraising}

Expenditures

F-Statistic on Instruments

(p-value)

Over-Identification Test (chi-square statistic) (p-value)

\# of Observations

\# of Charities

$\begin{array}{cc}(1) & (2) \\ \mathbf{- 1 . 0 7} & \mathbf{- 1 . 1 2} \\ (0.258) & (0.27) \\ & \\ \# 1 & \# 1 \\ 14.53 & 13.49 \\ (0.000) & (0.000) \\ 0.66 & 1.25 \\ (0.719) & (0.535)\end{array}$

$(3)$
$\mathbf{- 0 . 9 4}$
$(0.27)$

$\# 1$
12.57
$(0.000)$
1.32
$(0.517)$

$\begin{array}{cc}(4) & (5) \\ \mathbf{- 1 . 1 6} & \mathbf{- 1 . 0 5} \\ (0.27) & (0.26) \\ & \\ \# 1 & \# 1 \\ 15.40 & 14.59 \\ (0.000) & (0.000) \\ 1.02 & 0.60 \\ (0.601) & (0.743)\end{array}$

\section{(6)}

$\mathbf{- 1 . 2 8}$
$(0.33)$

$\# 1$
11.03

$(0.000)$

0.46
$(0.795)$

$\begin{array}{cc}-0.087 & -0.15 \\ (0.058) & (0.08) \\ & \\ 1.51 & 1.07 \\ (0.470) & (0.586)\end{array}$

$\mathbf{- 0 . 1 4}$
$(0.07)$

2.10
$(0.351)$

-0.19
$(0.11)$

2.95
$(0.229)$

$\mathbf{- 0 . 1 6}$
$(0.07)$

1.29
$(0.525)$

$\mathbf{- 0 . 2 0}$
$(0.09)$

0.66
$(0.817)$

4.81
$(0.97)$

$\mathbf{5 . 0 9}$
$(0.79)$$$
\text { \#1 }
$$

15.40

15.76

$(0.000)$

0.19

(0.000)

0.135
$(0.714)$

55,093

5,064
$\# 1$

$\# 1$

\subsection{4
$(1.19)$}

10.64

$(0.000)$

0.22

$(0.639)$

92,954

92,954
6,136 of Revenues Revenue**

$\begin{array}{ccc}(7) & (7) & (7) \\ -\mathbf{- 1 . 3 2} & \mathbf{- 0 . 6 0} & \mathbf{- 0 . 7 4} \\ (0.48) & (0.33) & (0.15) \\ & & \\ \# 1 & \# 3 & \# 1 \\ 6.30 & 8.54 & 33.45 \\ (0.000) & (0.000) & (0.000) \\ 0.06 & 7.48 & 2.99 \\ (0.972) & (0.024) & (0.224)\end{array}$

Notes: Robust and clustered standard errors reported in parentheses unless otherwise stated. Coefficients in bold $p<.05$, coefficients in bold \& italics $p<.10$. All regressions include the following covariates: charity fixed effects, charity specific time trend and square of charity specific time trend, year dummy variables The following measures at the neighbourhood (forward sortation area) level: average household income, square of average household income, total population share of population in the following age groups: less than 19, 55 to 64,65 and greater, share of population that has moved in the last five years, share of the population that immigrated since 1981, and share of the population that is a visible minority

The following measures at the provincial level: share of the seats in the provincial parliament that are held by liberals, the new democratic party, and parties other than conservatives. 


\section{Panel A: Effect of Government Funding on Private Giving}

Government Funding

Panel B: Effect of Government Funding on Fundraising Expenditures

Government Funding

Panel C: First Stage Results (Government Grants)

F-Statistic on Instruments

(p-value)

Coefficients on Instruments

Total tenure of members of federal parliament if affiliated with the party in power at the provincial level

Total tenure of federal parliament members affiliated with the provincial parliament party in power * If local member's political party is same as provincial parilaiment party in power

Total Government Funding to Non-Religious Charities in Province

Total tenure of members of federal parliament
Total Private Giving

$\begin{array}{cccc}(1) & (2) & (3) & -4 \\ -0.97 & -1.24 & -0.82 & -0.89 \\ (0.312) & (0.31) & (0.35) & (0.40) \\ & & & \\ -0.15 & -0.13 & -0.03 & -0.08 \\ (0.097) & (0.08) & (0.10) & (0.13) \\ & & & \\ & & & \\ 20.81 & 27.73 & 15.91 & 13.20 \\ (0.00) & (0.00) & (0.00) & (0.00)\end{array}$

$-0.61$

(0.13) 


\section{Panel A: Effect of Fundraising on Private Giving}

Fundraising expenditures

( $p$-value)

Coefficients on Instruments

Fundraising through door to door, anonymous sales

Fundraising through mail and phone solicitations

Fundraising through corporate campaigns, contracted fundraisers

\# of Observations

\# of Charities
4.73

(1.02)

17.80

$(0.00)$

0.78

(0.19)

Total Private Giving

5.19

(0.97)

4.60

(0.76)

21.88

34.20

$(0.00)$

$(0.00)$

1.79

(0.38)

2.28

(0.39)

54,234

6,327 